Borneo Journal of Social Science \& Humanities

DOI: https://doi.org/10.35370/bjssh.2021.3.2-07

e-ISSN: 2682-8235

(C) 2018, UCTS Publisher

Submitted: 04 October 202

Accepted: 23 December 2021

Published: 31 December 2021

\title{
A Study on the Factors Influencing the Secondary Schools Students' Career Self- Efficacy, in the Central Region Of Sarawak
}

\author{
Rabuan Mantine ${ }^{* 1}$, Rahmat Aidil Bin Djubair ${ }^{2}$ and Nadia Richard ${ }^{3}$ \\ ${ }^{1,2}$ School of Business and Management, University of Technology Sarawak \\ ${ }^{3}$ School of Foundation Studies, University of Technology Sarawak \\ *Corresponding author: rabuanm1@gmail.com
}

\begin{abstract}
This study is to investigate the factors that are expected to influence the secondary schools students' career self-efficacy in the central region of Sarawak. This study was conducted against the backdrop of the current evolving career choices, where traditional occupations are being replaced by new ones, as well as the ongoing discussion and debate on the academic streaming direction of the Malaysian education system. Placing so much emphasize on academic streaming as the only solution may inadvertently overshadows other important factors influencing students' future career direction. Thus, in view of the evolving career choices, besides subject or academic, the other factors such as family, teacher and peer, which form the central aspects of students' life are selected and analyzed on their influence on students' career self-efficacy. The study covers four rural and two urban schools out of 25 secondary schools in the central region, involving 535 respondents. To measure the effect the respondents in the selected schools were required to respond to the questionnaire on the selected factors. The data was analyzed and interpreted using multiple regression analysis. The findings from the data analysis show that family is the most important factor in influencing the students' career self-efficacy and followed by the subject which comes second. Teacher also yields positive result, however, unlike family and subject, teacher has influence only on the selected sub-groups of the students i.e. female, rural and art students. Oddly, peer is the sole factor that has no influence at all to the students' career self-efficacy. These results provide meaningful information for the stakeholders of the education in the public schools such as teachers, counselors as well as policy makers to refine targeted needs as well as policies to improve the confident level or students' career self-efficacy.
\end{abstract}

Keywords: Career self-efficacy, Academic Streaming, Peer Pressure, Career Decision

\section{Introduction}

Students' career inspiration may start early in life but serious career considerations can only practically starts during the upper secondary schools where students are on the path of making a commitment in a progress towards a career choice. In the Malaysian mainstream structured school system, students generally have to pursue either the science or arts stream in the upper secondary school (Form 4/Age 16) (Ministry of Education Malaysia, n.d.). After completion of secondary school (Form 5/Age 17) science stream students are opened to a myriad of opportunities either by pursuing higher education or Technical Vocational Education and Training (TVET) programs (Ministry of Education Malaysia, 2013) and are not limited to 'science' programs but also can 
Borneo Journal of Social Science \& Humanities

DOI: https://doi.org/10.35370/bjssh.2021.3.2-07

e-ISSN: 2682-8235

(C) 2018, UCTS Publisher

Submitted: 04 October $2021 \quad$ Accepted: 23 December $2021 \quad$ Published: 31 December 2021

venture into art programs such as social science, humanities, education (special, sports, language, music, early child, etc.), business, communications, art (graphic media, animation, etc.), hospitality and human resources. Unfortunately, art stream students may have to contend with art programs which, off course, are not less rewarding or lesser choice, and forgo any inspiration to become doctors, pharmacies, chemist or other related science programs or fields. Needless to say, due to streaming in education system, Form 4 level is the important career path starting point for a student.

Due to countless choices of careers nowadays, where some are new emerging ones phasing out traditional occupations (Phillpott, 2017) it is not uncommon for students to look up to parents, teachers, or even fellow students for career advice or guidance. At upper secondary school level some students may have clear career goals but some are still undecided. The word 'undecided' here may seemed to carry negative connotation but according to McAuliffe (1992), it is a normal experience and expected developmental process without possessing adequate amounts of information with which to make an informed decision. It is therefore considered as a temporary state during which the individual collects information about him or herself and potential careers as well as gains confidence about making the decision or choosing to wait until a decision is necessary (Salomone, 1982).

Irrespective of whether a student is from science or art stream, after the completion of Form 5 (Age 17) he or she should have a clear career path to progress on. Undecidedness at later stage, especially while pursuing higher education or TVET may lead to changing of courses or even dropouts or failures.

However, the framing of the academic streaming as the only solution to students' career choice, as shown on dominating ongoing topic of discussion and contention in Malaysia on the science and art academic streaming (Menon, 2019), maybe misplaced considering many other non-academic factors surrounding students' life such as parents, teachers and peers are equally important. As the career choices evolve, academic streaming may not as important factor after all, as students may now choose career which has no noticeable connection with his/her school academic streaming either from art or science stream classes.

Therefore, while wishing all the relevant parties surrounding student's life, such as parents, teachers (or school counselors) and peers to participate in the process of developing the students' career self-efficacy, we are still not sure how significant of each of these factors to the students' career choice, at least in the schools selected for this study. Based on the previous Malaysian study by Ismail et al. (2019) conducted in secondary schools in Terengganu shows that the science stream student group is higher in career self-efficacy than the non-science stream student group. In another Malaysian study by Hashim and Embong (2015), parents are more influential to students' career choice in accounting than peers. The American study on the influence of teachers by Faitar and Faitar (2013) found that teachers of the same minority background have more influence to minority students in TVET career self-efficacy.

As the above studies are from different time and demographic settings, the results may not necessarily represent the present local scenario and it is therefore important for this study to examine the significant influence of all these factors in shaping up the students' career self-efficacy in the secondary schools in the central region of Sarawak. 
Borneo Journal of Social Science \& Humanities

DOI: https://doi.org/10.35370/bjssh.2021.3.2-07

e-ISSN: 2682-8235

(C) 2018, UCTS Publisher

Submitted: 04 October 2021

Accepted: 23 December 2021

Published: 31 December 2021

\section{Research objectives}

The main objective in the study is to investigate the effect of various factors which form central parts of students' life such as the subjects taught at school, teachers, parents and peers on the students' career self-efficacy.

Theoretically, based on academic streaming, cluster or similar types of class setting, students are grouped and taught similar subjects. Students from science stream for have similar science 'core' subjects such as physic, chemistry, biology, additional mathematic/algebra, which are replaced by a form of generalized version of science and modern mathematics in the art stream with additional subjects such as accounting, economics, entrepreneurship, geography and commerce. The academic streaming is designed to enable students to motivate each other because they possess similar abilities (Fabien, 2018) and as such provides possible match of subjects that the students most likely to enjoy and most likely succeed academically. Thus, the success of academic streaming would finally lead to career self-efficacy.

Factors such as parents, teachers, and peers are not less important to students. Students often look up at their parents as their main source of inspiration and influence. Although, the parents may not be involved in the students' academic undertaking, the students may also listen to their parents for career choice and advice. Similarly, this analogy could also be applied to teachers or peers which might have influence on students' career self-efficacy. Unlike parents, teachers have a very significant, lifelong impact on all of their students due to class academic interaction. However, good teachers may also affect students much more broadly than through their impact on academic achievement (Jackson, 2018). Peers, on the other hand, may influence students' career decisions in a number of ways, although students may deny seeking validation directly of their career decisions from their peers (Mtemeri, 2020).

\section{Literature Review}

Early psychologist in social cognitive theory, Albert Bandura (Bandura, 1977) suggests that self-efficacy beliefs and outcome expectations shape people's awareness, interests, goals, actions, and eventually their attainments. Additionally, he suggests self-efficacy beliefs are also influenced by contextual factors such job opportunities, access to training opportunities and financial resources. Later researchers, Taylor and Betz (1983) applied the same theory of self-efficacy but focusing on individuals' confidence in engaging in activities associated with choosing a route or vocational education and career commitment. As the theory evolves, the definition of self-efficacy also progresses. Lent et al. (1994) clarified that self-efficacy as the expectations that are neither mere ego expressions from the inner-self nor sole objective measurements from the external world but rather, a subjective self-judgements that are both cognitive in nature and socially constructed. Subsequently, many researchers have embarked on studies linking selfefficacy with various variables such as gender, peers, teachers, parents, and subjects taught at school). The subsequent paragraphs are the review of some of the studies.

\section{School Subjects and Academic Streaming/Clustering}

Previous studies on academic streaming practices also yield interesting perspective on the subjects taught at schools where students were grouped and placed in different classes and taught different subjects. Salinitri (2006), in the study in the schools in 
Borneo Journal of Social Science \& Humanities

DOI: https://doi.org/10.35370/bjssh.2021.3.2-07

e-ISSN: 2682-8235

(C) 2018, UCTS Publisher

Submitted: 04 October $2021 \quad$ Accepted: 23 December $2021 \quad$ Published: 31 December 2021

Ontario, Canada, finds that, based on self-efficacy scales, the self-efficacies of students in applied classes were found to be lower than those in academic classes when considering attainment of high grades. Also, the magnitude of the self-efficacy was found to be lower in the applied stream students than in the academic students. The reform in the academic streaming system also may allow students to attend remedial course later which may fit his/her future career choice like in the study in Canada

The main difference between applied courses and academic courses is in the approach to learning (Counter, 2016). Academic courses are focused on abstract reasoning to teach subjects, and applied courses focus on hands-on activities. In the education reform policy, the academic and applied courses are supposed to be inclusive and flexible, giving students options without locking them in. Students can transfer between applied to academic courses by attending a remedial course. Thus, the economic reform policy introduced in Ontario as stated by Counter (2016) recognizes that academic streaming may not be the inhibiting factor to students' career progress by locking them in one set of subjects as more options could be applied by introducing remedial course later.

Similarly, the Malaysian study by Ismail et al. (2019), showed that the level of students' career self-efficacy was significantly different in accordance with their study streams where the science stream student group registers higher career self-efficacy than non-science stream student group. The study, however, was conducted only on the secondary schools in Terengganu, which in terms of demographic setting may not be representative to other parts of Malaysia.

\section{Self-Efficacy, Gender, and Career Decision}

The study of gender influence on career self-efficacy seemed not to come with the same conclusion. In a study of the connection between the perceived self-efficacy on the career decision-making among teenagers Crisan and Turda (2015) find that there was an insignificant negative correlation between gender and career indecision, however, between self-efficacy on making career decisions and gender of participants there was a significant positive correlation. Whereas, in another study by Chung et al. (2013) on the perceptions of gender awareness and considerations in career choices of medical students in a medical school in Taiwan, it was found that gender as a factor effecting career choice. Thus, there was no common conclusion on the influence of gender in the career self-efficacy.

\section{Peer Pressure and Career Decision}

The results of previous studies on the peer influence on students' career self-efficacy seemed somewhat positive, although not the overwhelming when compared with other factors. The findings of a study by Hashim and Embong (2015), where they investigated the level of influence between parents and peers of Malaysian school students in selecting their career choice as accountants revealed that parents, mothers, in particular were more influential in career choice of the secondary school students compared to their peers.

The findings of a later study on Kenyan youth by Ogutu et al. (2017) suggest that peer pressure directly influences student's career decision-making. From the research, it was concluded that peer pressure influenced career decision making among secondary school students in Busia County and as such, recommended career guidance in schools 
Borneo Journal of Social Science \& Humanities

DOI: https://doi.org/10.35370/bjssh.2021.3.2-07

e-ISSN: 2682-8235

(C) 2018, UCTS Publisher

Submitted: 04 October $2021 \quad$ Accepted: 23 December $2021 \quad$ Published: 31 December 2021

to be enhanced to create awareness by conducting regular career activities. Other study

on peer influence by Liu et al. (2021), although not directly on the career decision, suggests positive impact of peers with a higher social preference to secondary school students' justice where students of low social visibility are more strongly influenced by their peers. Nevertheless, all these studies suggest positive influence of peer not only to the students' career-self efficacy but also other social aspect of the students as well.

\section{Family, Parents and Teachers' influence}

All the previous studies on the influence of family in different family settings such as parents as well as extended family setting i.e. nucleus family to students' career choice show positive correlations. The result of a study on factors that influence the choice of career pathways among high school students in Midlands Province of Zimbabwe by Mtemeri (2007) revealed that family members, both nucleus and extended, had an influence on students' choice of careers. The influence of mothers and fathers was rated highly as compared to other family members. The study also acknowledged the importance of proper training and as such recommends training of parents to enhance their knowledge in helping students' career choice.

Another study in identifying which family environment have an impact on adolescent decision for a future career was conducted by Palos and Drobot (2010) where the results suggest that parents rather give their children psychosocial support than take concrete action that would facilitate the adolescents' decision regarding their career. The study identified supports such as encouraging the child and supporting the child's decisions, discussions in which the parents express their interest for the child's activities as beneficial to their children. Unfortunately, the study finds parents' behaviors oriented towards concrete career-related actions, such as providing informative materials about jobs, taking part on various career development workshops or on aptitude tests, have a much lower frequency. However, according to Thompson (2021), the function of parents may increasingly become mediator or merely gatekeeper of their children's involvement with peers and activities outside the family. Their communication and practice of values, though, still contributes to children's academic achievement, moral development, and activity preferences (Thompson, 2021).

The importance of teachers on students' academic achievement as well as career efficacy was also subject of many studies. The involvement of teachers with similar minority ethnic background of the students seemed to yield better results. This study was conducted by Faitar and Faitar (2013) to analyze the students' perception on the influence of teachers and counselors in their Science, Technology, Mathematics and Engineering (STEM) career choice in a New York college. A survey was given to undergraduate students, from minority background, enrolled in Mathematics and Natural Sciences, Physical Therapy, Nursing, and Physician Assistant programs. The result suggests participation of teachers and administrators of minority background in the upper middle- and high-school tracking process will stimulate an increased attention toward minority students with abilities for STEM specializations, and could potentially further their career in well-paying high-demand jobs.

However, the teachers' qualifications seemed do not have any influence on students' academic achievement. Kosgei et al. (2013) conducted a study in Nandi District, Kenya targeting sample population of teachers of all 26 public secondary 
Borneo Journal of Social Science \& Humanities

DOI: https://doi.org/10.35370/bjssh.2021.3.2-07

e-ISSN: 2682-8235

(C) 2018, UCTS Publisher

Submitted: 04 October $2021 \quad$ Accepted: 23 December $2021 \quad$ Published: 31 December 2021

schools. The study findings, however, suggest that there was no significant relationship between teacher qualification and student academic achievement.

\section{Methodology}

\section{Sample Population and Category}

The research was conducted based on a survey-based design study. Whereas the population sampling adopted was based on cluster sampling technique since the population was divided into clusters according to science and art classes. The characteristics of this cluster sampling is heterogeneous as the respondents are from different schools. The survey was conducted in six schools or 25 percent of the total twenty five secondary schools in Sibu and Mukah divisions, representing the central region of Sarawak, involving a total of 535 upper-secondary and Form 6 school students. As shown in Table 1, the samples are represented by equitable number of male $(\mathrm{N}=251$, $46.9 \%)$ and female students $(\mathrm{N}=284,53.1 \%)$ from 4 rural schools $(\mathrm{N}=389,72.7 \%)$ and 2 urban schools $(\mathrm{N}=146,27.3 \%)$. Half of the students are from Form 4 (Age 16) $(\mathrm{N}=$ 278, 52.0\%) and another half are from Form 5 and Form 6 (Age 17\&18) $(\mathrm{N}=257,48.0$ $\%)$. The samples also show a good balance of both art stream $(\mathrm{N}=288,53.8 \%)$ and science stream students $(\mathrm{N}=247,46.2 \%)$.

\section{Table 1: Demographic Profile of Respondents}

\begin{tabular}{l|l|c|c|}
\multicolumn{2}{l|}{ Demography } & \multicolumn{1}{c|}{ Frequency } & Percentage \\
\hline \multirow{2}{*}{ Gender } & Male & 251 & $46.9 \%$ \\
& Female & 284 & $53.1 \%$ \\
Area & Rural (4 schools) & 389 & $72.7 \%$ \\
& Urban (2 schools) & 146 & $27.3 \%$ \\
\multirow{2}{*}{ Age } & Form 4 & 278 & $52.0 \%$ \\
\multirow{2}{*}{ Stream } & Form 5/6 & 257 & $48.0 \%$ \\
& Art & 288 & $53.8 \%$ \\
& Science & 247 & $46.2 \%$
\end{tabular}

Source: Author

\section{Questionnaires}

In this study, the aim was to examine various influences on students' career self-efficacy. Thus, we developed a questionnaire (Table 2) that seeks to measure the perceived factors as potential influence. Specifically, this questionnaire aims to establish students' evaluation on how important these factors, namely subject, teacher, family, and peer are in influencing their career self-efficacy. To measure this construct, several Likert-Type items are added onto the questionnaire. The fifteen questions in the questionnaire (Table 2) represent the five variables. All items are responded to on a Likert scale of 1 to 5 , where $5=$ strongly agree and $1=$ strongly disagree. This was so throughout the scale a high score on a question indicates a high belief in perceived task value.

Table 2: Questionnaires

\begin{tabular}{cll}
\hline Variable & & Questions \\
\hline \multirow{2}{*}{ Self- } & 1. & I know which career should I choose \\
efficacy & 2. I am confident with my knowledge of my current chosen career \\
& 3. & I think I am currently in the right path towards achieving my career goal \\
\hline
\end{tabular}


Borneo Journal of Social Science \& Humanities

DOI: https://doi.org/10.35370/bjssh.2021.3.2-07

e-ISSN: 2682-8235

(C) 2018, UCTS Publisher

Submitted: 04 October $2021 \quad$ Accepted: 23 December $2021 \quad$ Published: 31 December 2021

4. Subjects provided at school give me enough information regarding which career should I choose

Subject 5. I learn most about my chosen career from subject thought at school

6. Subject at school motivated me to choose my current career pathway

7. Teachers provide me with enough example and guidance of career awareness

Teacher 8. Teachers included career awareness in subject they are teaching

9. Teacher encouraged me to be more aware of the jobs and career that I should take

10. My family guide and show me of which career that suitable for me

Family 11. My family has high expectations of a certain career which I should focus on

12. My family motivates me to choose my current career pathway

13. My friend guides me towards the career of my choice

Peer 14. My friend motivates me to choose my current preferred career

15. I always looked up at my friend for choosing my future career

Source: Author

\section{Validity and Reliability Tests}

Seeking to examine the validity of the questionnaire, Pearson product moment correlations using SPSS was conducted. All the total score values $r$ obtained (Table 3) for the fifteen item-scale in the questionnaire are significant (2-tailed) at $\mathrm{p}<0.05$ and exceed Pearson correlation product moment critical values $r_{c}=0.085$ indicating the convergence validity of the research instrument.

Table 3: Validity Testing: Pearson Correlations

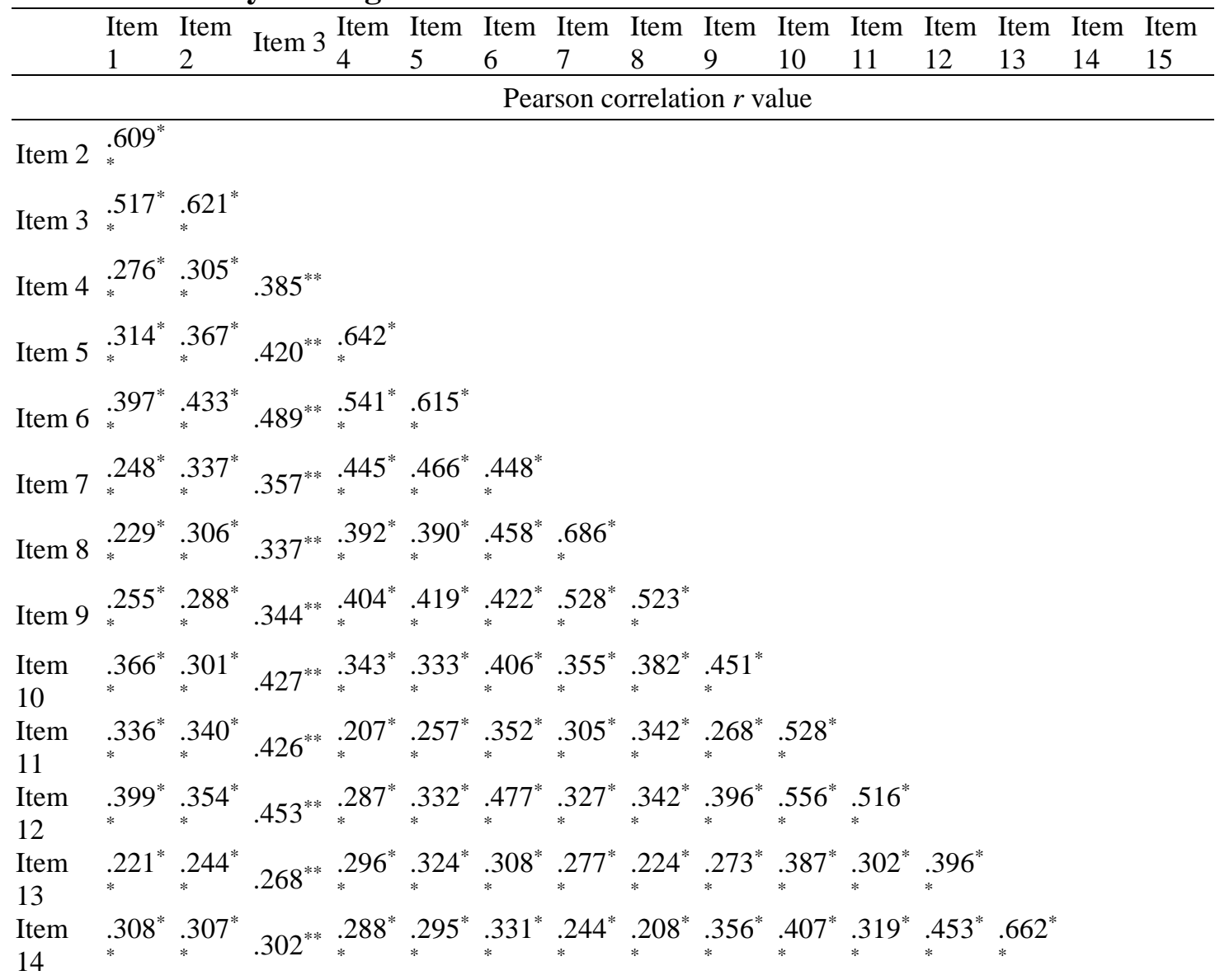


Borneo Journal of Social Science \& Humanities

DOI: https://doi.org/10.35370/bjssh.2021.3.2-07

e-ISSN: 2682-8235

(C) 2018, UCTS Publisher

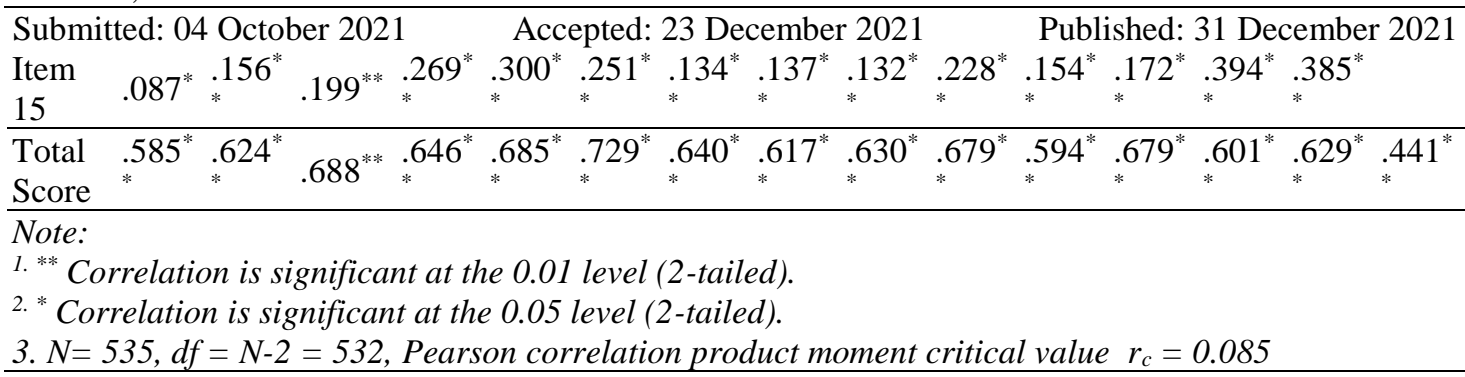

Whereas, based on the Cronbach's Alpha' score (Table 4), the internal consistency of the questions of the questionnaire in measuring the same construct (perceived task value) are acceptable $(0.8>\alpha>0.7)$ for variables family and peer and $\operatorname{good}(0.9>\alpha>0.8)$ for other variables i.e. career self-efficacy, teacher and subject.

Table 4: Reliability Testing: Cronbach Alpha

\begin{tabular}{cccc}
\hline Variables & Number of Questions & Cronbach's Alpha $\alpha$ & Internal Consistency \\
\hline Self-Efficacy & 3 & .804 & Good \\
Subject & 3 & .817 & Good \\
Teacher & 3 & .805 & Good \\
Family & 3 & .774 & Acceptable \\
Peer & 3 & .730 & Acceptable \\
\hline
\end{tabular}

Note: $\mathrm{N}=535$

Source: Author

\section{Ordinary Least Squares Regression (OLS) Method}

The OLS method corresponds to minimizing the sum of square differences between the observed and predicted values. In this analysis multiple regression analysis was conducted to observe the influence of the four selected independent variables, namely the teacher, family, peer and subject on the independent variable i.e. the students' career self-efficacy. The OLS method are applied on the aggregated data as well as the disaggregated data in various demographic sub-groups such i.e. gender, area, age and academic stream to measure the significance of the influence of each variable given different group aggregation. The linear representation of the independent and dependent variables are shown as per equation below:

$$
\text { Career Self-Efficacy }=\alpha+\beta 1 \text { Subject }+\beta 2 \text { Teacher }+\beta 3 \text { Family }+\beta 4 \text { Peer }++\varepsilon i
$$

Where;

Dependent variable;

Career Self-Efficacy = average Likert scale value based on the questionnaire on selfefficacy

Independent variables;

Subject, Teacher, Family, and Peer = are the independent variables represented by the average Likert scale value from the questionnaire on the respective variables.

$\alpha=$ the intercept (the value of dependent variables when the value of all independent variables are zero); 
Borneo Journal of Social Science \& Humanities

DOI: https://doi.org/10.35370/bjssh.2021.3.2-07

e-ISSN: 2682-8235

(C) 2018, UCTS Publisher

Submitted: 04 October $2021 \quad$ Accepted: 23 December $2021 \quad$ Published: 31 December 2021

$\beta 1$ to $\beta 4=$ are the vectors or slopes associated with the independent variables.

$\varepsilon i=$ the error terms associated with unobservable factors that may affect the dependent variable.

\section{Findings}

The results of the regression analysis is shown in the Table 5 below and discussed in the subsequent paragraphs based on the aggregated data and the four selected demography.

Table 5: Regression Analysis Results

\begin{tabular}{|c|c|c|c|c|c|c|c|c|c|}
\hline & & & $\mathrm{N}$ & $\mathrm{r}^{2}$ & 氖 & $\begin{array}{l}\frac{\ddot{d}}{2} \\
\ddot{E}\end{array}$ & 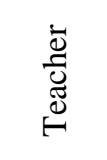 & 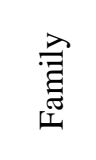 & $\begin{array}{c}\dot{\Phi} \\
\stackrel{D}{0}\end{array}$ \\
\hline \multicolumn{3}{|c|}{ Coefficients } & & & $\alpha$ & $\beta_{1}$ & $\beta_{2}$ & $\beta_{3}$ & $\beta_{4}$ \\
\hline \multicolumn{3}{|c|}{ Aggregated Data } & 535 & .381 & $\begin{array}{c}.912 \\
(.000 *)\end{array}$ & $\begin{array}{c}.297 \\
\left(.000^{*}\right)\end{array}$ & $\begin{array}{c}.049 \\
(.301) \\
\end{array}$ & $\begin{array}{c}.372 \\
(.000 *)\end{array}$ & $\begin{array}{c}.02 \\
(.601) \\
\end{array}$ \\
\hline \multirow{8}{*}{ 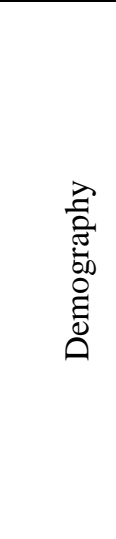 } & \multirow{2}{*}{ 1. Gender } & Male & 251 & .401 & $\begin{array}{c}.995 \\
(.000 *) \\
\end{array}$ & $\begin{array}{c}.375 \\
(.000 *)\end{array}$ & $\begin{array}{c}-.035 \\
(.588) \\
\end{array}$ & $\begin{array}{c}.421 \\
(.000 *)\end{array}$ & $\begin{array}{r}.025 \\
(.655) \\
\end{array}$ \\
\hline & & Female & 284 & .389 & $\begin{array}{c}.487 \\
(.057)\end{array}$ & $\begin{array}{c}.242 \\
(.000 *)\end{array}$ & $\begin{array}{c}.191 \\
\left(.006^{*}\right)\end{array}$ & $\begin{array}{c}.323 \\
(.000 *)\end{array}$ & $\begin{array}{c}.077 \\
(.133)\end{array}$ \\
\hline & \multirow{2}{*}{ 2. Area } & Rural & 389 & .407 & $\begin{array}{c}.699 \\
(.000 *)\end{array}$ & $\begin{array}{c}.279 \\
\left(.000^{*}\right)\end{array}$ & $\begin{array}{c}.130 \\
\left(.027^{*}\right)\end{array}$ & $\begin{array}{c}.354 \\
(.000 *)\end{array}$ & $\begin{array}{c}.013 \\
(.766) \\
\end{array}$ \\
\hline & & Urban & 146 & .367 & $\begin{array}{c}1.119 \\
(.000 *)\end{array}$ & $\begin{array}{c}.370 \\
\left(.000^{*}\right)\end{array}$ & $\begin{array}{l}-.046 \\
(.575) \\
\end{array}$ & $\begin{array}{c}.392 \\
(.000 *) \\
\end{array}$ & $\begin{array}{c}.003 \\
(.965) \\
\end{array}$ \\
\hline & \multirow{2}{*}{ 3. Age } & Form 4 & 278 & .309 & $\begin{array}{c}1.169 \\
(.000 *)\end{array}$ & $\begin{array}{c}.257 \\
(.000 *)\end{array}$ & $\begin{array}{c}.039 \\
(.545)\end{array}$ & $\begin{array}{c}.367 \\
(.000 *)\end{array}$ & $\begin{array}{c}.012 \\
(.821) \\
\end{array}$ \\
\hline & & Form 5/6 & 257 & .485 & $\begin{array}{c}.447 \\
(.054)\end{array}$ & $\begin{array}{c}.372 \\
(.000 *)\end{array}$ & $\begin{array}{c}.080 \\
(.250) \\
\end{array}$ & $\begin{array}{c}.357 \\
(.000 *) \\
\end{array}$ & $\begin{array}{c}.042 \\
(.430) \\
\end{array}$ \\
\hline & \multirow{2}{*}{ 4. Stream } & Art & 288 & .432 & $\begin{array}{c}.661 \\
(.002 *) \\
\end{array}$ & $\begin{array}{c}.266 \\
(.000 *) \\
\end{array}$ & $\begin{array}{c}.172 \\
\left(.007^{*}\right) \\
\end{array}$ & $\begin{array}{c}.363 \\
(000 *) \\
\end{array}$ & $\begin{array}{c}.001 \\
(.990) \\
\end{array}$ \\
\hline & & Science & 247 & .348 & $\begin{array}{c}1.141 \\
(.000 *)\end{array}$ & $\begin{array}{c}0.337 \\
(.000 *)\end{array}$ & $\begin{array}{l}-0.071 \\
(0.311) \\
\end{array}$ & $\begin{array}{c}0.37 \\
(.000 *)\end{array}$ & $\begin{array}{c}0.042 \\
(0.474) \\
\end{array}$ \\
\hline \multicolumn{10}{|c|}{$\begin{array}{l}\text { Note: } \\
\text { 1. Dependent variable: } \text { Career Self-Efficacy } \\
2(*) \text { significant at } 0.05 \text { level }\end{array}$} \\
\hline
\end{tabular}

\section{Aggregated Data}

The results of the aggregated data $(\mathrm{N}=535)$ show that the students' career self-efficacy was significantly influenced only by family $(\beta 2=.372)$ and followed by subject $(\beta 4=.297)$. Whereas teacher and peer variables are insignificant. The variables also explained a significant proportion of about 38.1 percent of the variance in career selfefficacy scores $(\mathrm{R} 2=.381)$.

\section{Demography 1-Gender}

In the results of the first disaggregated data under gender demography group, the male students $(\mathrm{N}=251)$ show that the students' career self-efficacy was significantly influenced by family $(\beta 2=.421)$ and subject $(\beta 4=.375)$. Similar to aggregated data, teacher and peer are insignificant. The variables explained a significant proportion of about 40.1 percent of variance in career self-efficacy scores $(\mathrm{R} 2=.401)$. The female students $(\mathrm{N}=284)$ on the other hand, register additional variable, namely teacher $(\beta 1=.191)$ as significant in influencing students' career self-efficacy besides family 
Borneo Journal of Social Science \& Humanities

DOI: https://doi.org/10.35370/bjssh.2021.3.2-07

e-ISSN: 2682-8235

(C) 2018, UCTS Publisher

Submitted: 04 October $2021 \quad$ Accepted: 23 December $2021 \quad$ Published: 31 December 2021

$(\beta 2=.323)$ and subject $(\beta 4=.242)$. Unlike male students, only variable peer was insignificant. Similarly, the variables also explained $38.9 \%$ of the variance $(\mathrm{R} 2=.389)$.

\section{Demography 2- Area}

In the second disaggregated data represented by area demography group, the results on the analysis of the rural school students $(\mathrm{N}=389)$ show the students' career self-efficacy was also significantly influenced by teacher $(\beta 1=.130)$ besides family $(\beta 2=.354)$ and subject $(\beta 4=.279)$. Only variable peer was insignificant. The variables also explained a significant proportion of about 40.7 percent of variance in career self-efficacy scores $(\mathrm{R} 2=.407)$. The urban school students $(\mathrm{N}=146)$ on the other hand, only register family $(\beta 2=.392)$ and subject $(\beta 4=.370)$ as significant. Unlike rural school students, variable teacher and peer are insignificant. The variables also explained a significant proportion of about 36.7 percent of variance in career self-efficacy scores $(\mathrm{R} 2=.367)$.

\section{Demography 3-Age}

The third disaggregated data under age demography group's results for Form 4 students $(\mathrm{N}=278)$ show that the students' career self-efficacy was only significantly influenced by family $(\beta 2=.367)$ and subject $(\beta 4=.257)$. Whereas, variables teacher and peer are insignificant. The variables also explained a significant proportion of about 30.9 percent variance in career self-efficacy scores $(\mathrm{R}=.309)$.

Similar results were also registered by the higher age group, i.e. Form 5/6 students $(\mathrm{N}=257)$ with family $(\beta=.357)$ and subject $(\beta 4=.372)$ significantly influencing the students' career self-efficacy. Similar to the results of Form 4 students, variable teacher and peer were insignificant. The variables also explained a significant proportion of about 48.5 percent variance in career self-efficacy scores $(\mathrm{R} 2=.485)$.

\section{Demography 4- Academic Stream}

Finally, the disaggregated data under academic stream demography group, the art stream students $(\mathrm{N}=288)$ show that the students' career self-efficacy was also significantly influenced by teacher $(\beta 1=.172)$ besides family $(\beta 2=.363)$ and subject $(\beta 4=.266)$. Only variable peer was insignificant. The variables also explained a significant proportion of about 43.2 percent variance in career self-efficacy scores $(\mathrm{R} 2=.432)$. On the other hand, the career self-efficacy of the science stream students $(\mathrm{N}=247)$ were only significantly influenced by family $(\beta 2=.370)$ and subject $(\beta 4=.337)$. Unlike the results of the art stream students, two variables i.e. teacher and peer were insignificant. The variables also explained a significant proportion of about 34.8 percent variance in career self-efficacy scores $(\mathrm{R} 2=.348)$.

\section{Discussions}

The discussions below are based on the results of the four variables namely subject, family, teacher and peer, under different demographic settings in the study in comparison to the previous similar studies.

\section{Subject}

The results of this study thus placed subject as second important factor after family in influencing students' career self-efficacy. Similar previous studies also supported this finding. In the analysis of African studies, Abrahams et al. (2015) find the interest in 
Borneo Journal of Social Science \& Humanities

DOI: https://doi.org/10.35370/bjssh.2021.3.2-07

e-ISSN: 2682-8235

(C) 2018, UCTS Publisher

Submitted: 04 October $2021 \quad$ Accepted: 23 December $2021 \quad$ Published: 31 December 2021

the subject was a factor that has a lot of impacts on making career choices by the students, although in other demographic settings, financial factors are the deciding factors in career choices of students. The argument put forward by Zang (2007) was that personal liking of an individual towards a particular subject contributes to their career selection decision whereas Shertzer and Stone (1981) argue that interest depicted by students in some subjects will mostly lead to the better examination performance and selection of profession in the same direction. Although no data was collected for the students' family financial standing in this study, the results suggest, irrespective of students' family financial positions based on income disparity between rural and urban population, the students' career self-efficacy was significantly influenced by subject. Subject also found to be important factor across all other disaggregated data sets i.e. gender group, age group and academic stream group demography. As such, the academic steaming practice by segregating students to science and art stream classes in school, does not hinder the influence of subject to students' self-efficacy.

\section{Family}

The influence of family on the students' career self-efficacy was as expected. The impact of family influence on students' career self-efficacy in this study is supported by similar studies by previous researches. Palos and Drobot (2010) argue that psychosocial support by parents who are affectionate, tolerant, stimulative and more involved in the children's vocational development are as important as initiating concrete career plans for their children. James (2000) suggests that the home environment and upbringing lay the foundation of a child's personality. In essence, the values of the parents are inadvertently transferred into the child. Irrespective of whether the students are from rural and urban schools, male or female, art or science, young or old, the results of this study suggest that family is very important factor in influencing students' career self-efficacy.

\section{Teacher}

Another interesting finding was the teacher's influence on rural school students, female students and art students' career self-efficacy. Although no exact same past studies can be found for comparison purposes, previous study by Ali et al. (2008) on rural Appalachian high school students offers some explanation on the lack of career aspirations among them. The study inferred that their poor socioeconomic background contributes to their lack of career self-efficacy. It should be noted that, the poor rural Appalachia populations often experience cultural marginalization from the mainstream U.S. culture. In South Africa, a comprehensive study by Ngesi (2003) reports that students from poor socioeconomic backgrounds are prone to making wrong career decisions. While the results and the arguments of the previous studies are reasonable, in the Malaysian context, we could explore the possibilities of current urbanization process taking place which stands at 75 percent in 2017 (New Straits Times, 2018) and increasing where more population from rural areas entering the workforce shifting from traditional farming to industry-based thus requiring them to rely more on teachers rather than their parents for career information.

Meanwhile, on the subject of gender, on the other hand, could be explained by a study by researchers, Chung et al. (2013) who find gender plays a role in confidence level and career choices among medical students in Taiwan. Female medical students were found to be less confidence as compared to male students. Still on the issue gender, 
Borneo Journal of Social Science \& Humanities

DOI: https://doi.org/10.35370/bjssh.2021.3.2-07

e-ISSN: 2682-8235

(C) 2018, UCTS Publisher

Submitted: 04 October 202

Accepted: 23 December 2021

Published: 31 December 2021

Saadin et al. (2016) observed career women often find work-life balance and gender stereotypes have significant relationship toward barriers for upward career advancement and understandably need more career guidance. Another plausible explanation in the Malaysian context is the increased participation of women in the workforce which stands at 53.5 percent in 2017 (Khazanah Research Institute, 2018), thus requiring them to enquire additional information of potential job opportunities which their parents and families could not provide.

The characteristic of the art stream students, on the other hand, were explained by the automatic streaming under the Malaysian education system. Based on academic results, the bottom half of the students were automatically lumped into art stream. Unlike science stream students, where the career fields were quite long established such as engineers, doctors, chemist, and information could be passed on from parents, the art stream students are open to limitless new fields and possibilities and thus need more guidance and exploration.

Eventually, although the influence of teachers on all the three sub-groups of female students, art students and rural school students could be explained for their common perceived disadvantages as highlighted by the results of previous researches, alternative explanations based on local demographic setting are rather upbeat and uplifting. The results offered educators or counselors an opportunity to explore and design targeted interventions at school level, especially the sub-demographic groups, to increase the students' confidence and expectations of their future.

\section{Peer}

In the final observation of the results, the absence of peer influence on students' career self-efficacy is rather puzzling but somehow refreshing, knowing well peer influence could sometimes be destructive where students could also be influenced by negative gang behavior (Adeniyi \& Jinadu, 2021). It has a deep impact on one's decision making ability, especially when it comes to choosing a course or a career path. Peer pressures e.g. for conformity and social acceptability, may lead to wrong decisions and difficulties. However, on the bright side, peer influence can also be positive. According to Harre and Lamb (1983, p.447), peer group plays an important part in providing social support and identity during adolescence. Peers are the primary component of an adolescent's social network and are relied upon more as sources of support and advice during this developmental period (Buhrmester, 1996; Brown, 1990). The only sensible explanation is that, perhaps, in the close-knit society of the population in the central region of Sarawak, urban or otherwise, family trumped peer influence on the students' career selfefficacy.

\section{Conclusions}

The ongoing discussion on academic streaming as well as the evolving nature of career choices have generated interest in the study on the impact of various factors to the students' career self-efficacy. However, the results of the previous studies cannot be made to fit the different demographic settings and due to time factor, may no longer valid. Nonetheless, the previous studies provide the basic framework for this study. This study was based on the premise that there are other factors such as parents, teachers and peers besides academic or subjects that influence the students' self-efficacy. Based on 
Borneo Journal of Social Science \& Humanities

DOI: https://doi.org/10.35370/bjssh.2021.3.2-07

e-ISSN: 2682-8235

(C) 2018, UCTS Publisher

Submitted: 04 October $2021 \quad$ Accepted: 23 December $2021 \quad$ Published: 31 December 2021

survey method, the data from 535 respondents from the six out of 25 secondary schools in the central region of Sarawak were analyzed and interpreted. The results showed that subjects taught at schools shown significant influence on students' career self-efficacy especially in the central region of Sarawak in both science and art stream classes which is a positive indication on the result of the academic streaming policy. Similar result also recorded by family as a major influence of students' career self-efficacy. Teacher, however has selective influence on demographic sub-groups of the students i.e. female, rural and also art students whereas, peer seemed to play no significant role. These results provide opportunities for the stakeholders of the education in the public schools such as teachers, counselors as well as policy makers to refine targeted needs as well as policies to increase the confident level or career self-efficacy of the students.

\section{Limitations of the Study}

Rural and urban categories used in this study do not reflect the economic backgrounds of the respondents. We decided not to put this information into the questionnaire as we think students would not be able to provide information accurately. Thus, the results between urban and rural demographic group should not be interpreted as representing economic backgrounds of the respondents. The selection of the schools in the central region of Sarawak also may not be representative of the other schools in other part of Sarawak due to demographic factor, among others. Thus, the results should be limited to the demographic area under study. The other challenge was the administration of the actual surveys as we did not want to disrupt the students' classes as well as to avoid the survey administration too close to their school exam schedule where students were more focused on their preparation for their exam.

\section{Suggestion for Future studies}

Although the results are useful in assessing the achievement of the academic streaming practice, where students are separated and taught subjects in science and art for science and art streams respectively, specific study should be conducted to refine policy on academic streaming for better matching of students' career self-efficacy and industry or national job demands or requirements. The study must be comprehensive and allinclusive which means the influence of other factors related to the students' life should also be taken into consideration.

\section{References}

Abrahams, F., Jano, R., \& van Lill, B. (2015). Factors Influencing the Career Choice of Undergraduate Students at a Historically Disadvantaged South African University. Industry and Higher Education, 29(3), 209-219.

Adeniyi, W.O. \& Awolowo, O. (2021). Influence of Peer Pressure on Gang Behaviour among Secondary School Students in Osun State, Nigeria. European Journal of Education and Pedagogy, 171-177.

Ali, S.R. \& McWhirter, E.H. (2006). Rural Appalachian Youth's Vocational/Educational Post-Secondary Aspirations: Applying Social Cognitive Career Theory. Journal of Career Development, 33, 87-111.

Bandura, A. (1977). Self-Efficacy: Toward A Unifying Theory of Behavioral Change. Psychological Review, 84(2), 191-215. 
Borneo Journal of Social Science \& Humanities

DOI: https://doi.org/10.35370/bjssh.2021.3.2-07

e-ISSN: 2682-8235

(C) 2018, UCTS Publisher

Submitted: 04 October $2021 \quad$ Accepted: 23 December $2021 \quad$ Published: 31 December 2021

Brown, B.B. (1990). Peer Groups and Peer Cultures. In S.S. Feldman \& G.R. Elliott (Eds.), at the threshold: The developing adolescent (pp. 171-196), Cambridge, MA: Harvard University Press.

Buhrmerter, D. (1996). Need Fulfillment, Interpersonal Competence \& The Development Contexts of Early Adolescence Friendship. In W.M. Bukowsk, A. F. Newromb \& W.W. Hartup (Eds.): The company they keep friendship in childhood and adolescence (pp.158-185) Cambridge, UK: Cambridge University Press.

Chung, Y.C., Lin, C.Y., Huang, C.N., \& Yang, J.H. (2013). Perceptions on gender awareness and considerations in career choices of medical students in a medical school in Taiwan. The Kaohsiung Journal of Medical Sciences, 29(11), 629-635.

Counter, A. (2016). Applied vs. Academic - What It All Means. Parenting Times. Retrieved from https://www.ottawaparentingtimes.ca.

Crisan, C. \& Turda, S. (2015). The Connection between the Level of Career Indecision and the Perceived Self-Efficacy on the Career Decision-Making among Teenagers. Procedia - Social and Behavioral Sciences, 209, 154 - 160.

Fabien, J.H. (2018). Streaming in Schools: The Benefits of Grouping Students by Ability. Retrieved on 22 March 2021. Retrieved from https://wehavekids.com/education/STREAMINGThe-benefits-of-streaming-insecondary-schools.

Faitar, G.M. \& Faitar, S.L. (2013). Teachers' Influence on Students' Science Career Choices. American International Journal of Social Science, 2(5), 10-16.

Harre, R. \& Lamb, R. (Eds.) (1983). The encyclopedic dictionary of psychology. Oxford, England: Blackwell.

Hashim, Hezlina M. \& Embong Abdul M. (2015). Parental and Peer Influences upon Accounting as a Subject and Accountancy as a Career. Journal of Economics, Business and Management, 3(2), 252-256.

Ismail, M.S., Yusoff, S.H.M., Embong, R., Jusoh, W.H.W., Shuhari, M.H., Abdullah, S.S., \& Yahaya, A. (2019). The Influence of Study Stream on Carrier SelfEfficacy among Secondary School Students. International Journal of Academic Research in Progressive Education and Development, 8(4), 516-524.

Jackson. C.K. (2018). What Do Test Scores Miss? The Importance of Teacher Effects on Non-Test Score Outcomes. Journal of Political Economy, 126(5), 1-62.

James, R. (2000). How School-Leavers Chose A Preferred University Course and Possible Effects on The Quality of The School-University Transition. Journal of Institutional Research, 9(1), 78-88.

Khazanah Research Institute. (2018). Part 2: The Malaysian Workforce: A Changing Landscape. Khazanah Research Institute Report. Retrieved from www.Krinstitute.Org/ Publications.

Kosgei, A., Mise, J.K., Odera, O., \& Ayugi, M.E. (2013). Influence of Teacher Characteristics on Students' Academic Achievement among Secondary Schools. Journal of Education and Practice, 4(3), 76-82.

Lent, R.W., Brown, S.D., \& Hackett, G. (1994). Toward a unifying social cognitive theory of career and academic interest, choice, and performance. Journal of Vocational Behaviour, 45, 79-122. 
Borneo Journal of Social Science \& Humanities

DOI: https://doi.org/10.35370/bjssh.2021.3.2-07

e-ISSN: 2682-8235

(C) 2018, UCTS Publisher

Submitted: 04 October $2021 \quad$ Accepted: 23 December $2021 \quad$ Published: 31 December 2021

Liu, Lisha, Xu, L., Liu, Lu, \& Li, Y. (2020) Positive influence of peers' interpersonal character on children's interpersonal character: The moderating role of children's and peers' social status. Journal of Adolescence, 79, 157-172.

McAuliffe, G.J. (1992). Assessing and Changing Career Decision-Making Self-Efficacy Expectations. Journal of Career Development, 19(1), 25-36.

Menon, S. (2019, Feb 15). Maszlee reveals plan to merge Science and Arts streams. The Star, Nation.

Ministry of Education Malaysia (2013). Malaysia Education Blueprint 2013-2025 (Pre-school to Post-secondary Education). Retrieved from https://www.moe.gov.my.

Ministry of Education Malaysia (n.d.). Secondary School- Introduction. Retrieved from https://www.moe.gov.my.

Mtemeri, J. (2020). Peer pressure as a predictor of career decision-making among high school students in Midlands Province, Zimbabwe. Global Journal of Guidance and Counselling in Schools: Current Perspectives, 10(3), 120-131.

Mtemeri, J. (2007). Factors Influencing the Choice of Career Pathways among High School Students in Midlands Province, Zimbabwe. PhD Thesis (Unpublished), University Of South Africa.

New Straits Times. (2018, March 12). Govt Prepares For Rapid Urbanisation. Retrieved from https://www.nst.com.my/.

Ngesi, M.J. (2003). A Study of Systematic Processes Influencing Educational Change in a Sample of Isi-Zulu Medium Schools. PhD Thesis, Unpublished. University of Natal, Pietermaritzburg, South Africa.

Ogutu, J.J.P., Odera, P., \& Maragia, S.N. (2017). The Effectiveness of Peer Pressure on Students' Career Decision Making in Secondary Schools in Kenya. International Journal of Humanities and Social Studies, III(3), 16-32.

Palos, R. \& Drobot, L. (2010). The Impact of Family Influence on the Career Choice of Adolescents. Procedia Social and Behavioral Sciences, 2, 3407-3411.

Phillpott, S. (2017). 13 Disappearing Jobs that Won't Exist in 2030. Career Addict. Retrieved from https://www.careeraddict.com.

Saadin, I, Ramli K, Johari., \& H, Harina, N.A. (2016). Women and Barriers for Upward Career Advancement - A Survey at Perak State Secretariat, Ipoh, Perak. 7th International Economics \& Business Management Conference. Procedia Economics and Finance, 35 , pp. $574-581$.

Salinitri, D. (2006). Streaming in secondary schools: Effects on Student Self-Efficacy from the Perspectives of the Students, Teachers, Administrators, and Counsellors. Unpublished Master Thesis, University of Windsor, Ontario, Canada. Retrieved from https:// scholar. uwindsor.ca

Salomone, P.R. (1982). Difficult Cases in Career Counseling: II-The Indecisive Client. Journal of Counseling \& Development, 60(8), 496-500.

Shertzer, B. \& Stone, S.C. (1981). Fundamentals of Guidance (4th Ed.). Boston, MA: Houghton Mifflin.

Taylor, K.M. \& Betz, N.E. (1983). Application of Self-Efficacy Theory to the Understanding and Treatment of Career Indecision. Journal of Vocational Behavior, 22, 63-81.

Thompson, R. (2021). Social and personality development in childhood. In R. Biswas-Diener $\&$ E. Diener (Eds), Noba textbook series: Psychology. Champaign, IL: DEF publishers. 
Borneo Journal of Social Science \& Humanities

DOI: https://doi.org/10.35370/bjssh.2021.3.2-07

e-ISSN: 2682-8235

(C) 2018, UCTS Publisher

Submitted: 04 October 2021

Accepted: 23 December 2021

Published: 31 December 2021

Zhang, W. (2007). Why IS: Understanding Undergraduate Students' Intentions To Choose An Information Systems Major. Journal of Information Systems Education, 18(4), 447458 